GU J Sci, Part C, 6(2): 385-398 (2018)

Gazi Üniversitesi
Fen Bilimleri Dergisi
PART C: TASARIM VE TEKNOLOJI
dergipark.gov.tr/http-gujsc-gazi-edu-tr

\title{
Toz Metal AA 2014-SiC-B 4 C Kompozit/Hibrit Malzemelerinin Mikroyapı ve Mekanik Özelliklerinin İncelenmesi
}

\author{
Hakan GÖKMEŞE ${ }^{1, *}$ Hakan BURAK KARADAĞ ${ }^{2}$ \\ ${ }^{1}$ Konya Necmettin Erbakan Üniversitesi, Seydişehir Ahmet Cengiz Mühendislik Fakültesi, Metalurji ve Malzeme Mühendisliği Bölümü, 42370, \\ Seydişehir/KONYA \\ ${ }^{2}$ Konya Necmettin Erbakan Üniversitesi, Mühendislik ve Mimarllk Fakültesi, Metalurji ve Malzeme Mühendisliği Bölümü, 42360, KONYA
}

$\underline{\mathbf{O z}}$

Makale Bilgisi

Başvuru: $12 / 12 / 2017$

Düzeltme: 08/02/2018

Kabul:27/02/2018

Anahtar Kelimeler

Toz metalurjisi

Aluminyum

Hibrit kompozit

Mikro yapr

Sertlik

Keywords

Powder metallurgy

Aluminum

Hybrid composite

Microstructure

Hardness
$\mathrm{Bu}$ çalışmada, toz metalurjisi yöntemiyle AA 2014 aluminyum alaşımı ve $\mathrm{B}_{4} \mathrm{C}-\mathrm{SiC}$ seramik parçacık takviyeli hibrit metal matrisli kompozit malzemelerinin üretimi, mikro yap1 ve mekanik özellikleri incelenmiştir. Bu amaçla, $\mathrm{SiC}$ (\%5-10-15), $\mathrm{B}_{4} \mathrm{C}(\% 5-10-15)$ ve $\mathrm{B}_{4} \mathrm{C}-\mathrm{SiC}$ (\%10-\%10) farklı hacim oranlarında seramik parçacık takviyeli kompozit ve hibrit kompozit malzemeleri aluminyum matris yapısında üretilmiştir. Matris ve takviye toz karışımları, tek yönlü olarak $700 \mathrm{MPa}$ altında blok numuneler şeklinde preslenerek, Argon atmosferinde $600^{\circ} \mathrm{C}$ sıcaklıkta 1 saat sinterlenmiştir. Üretimi gerçekleştirilen deney numuneleri, SEM (Taramalı Elektron Mikroskop), Optik mikroskop ve mikro sertlik (HV 0.1) ölçümleri bakımından karakterize edilmiştir. $\mathrm{B}_{4} \mathrm{C}$ ve $\mathrm{SiC}$ seramik parçacıklarının hacim oranın artışına bağlı olarak, aluminyum matris yapısında homojen bir dağılım sergilediği mikro yapı görüntüleri ile tespit edilmiştir. AA 2014 aluminyum alaşımına göre, artan $\mathrm{SiC}$ ve $\mathrm{B}_{4} \mathrm{C}$ seramik parçacık takviye oranına bağlı olarak, sertlik değerlerinin arttığ tespit edilmiştir. $\mathrm{B}_{4} \mathrm{C}-\mathrm{SiC}$ parçacık takviyeli hibrit kompozit malzemelerinde ise, $\% 15 \mathrm{~B}_{4} \mathrm{C}$ ve $\% 15 \mathrm{SiC}$ içeren tek seramik faz takviyesine göre nispeten mikro sertlik değeri azalmıştır.

\section{Examination of Microstructure and Mechanical Properties of Powder Metal AA 2014-SiC-B 4 C Composite / Hybrid Materials}

\begin{abstract}
In this study, the production, microstructure and mechanical properties of AA 2014 aluminum alloy and $\mathrm{B}_{4} \mathrm{C}-\mathrm{SiC}$ ceramic particle reinforced hybrid metal matrix composite materials were investigated by powder metallurgy. For this purpose, $\mathrm{SiC}(5-10-15 \%), \mathrm{B}_{4} \mathrm{C}(5-10-15 \%)$ and $\mathrm{B}_{4} \mathrm{C}-\mathrm{SiC}(10 \%-10 \%)$ ceramic particle reinforced composite and hybrid composite materials were produced in different volume ratio on aluminum matrix structure. Matrix and reinforcement powder blends were sintered under argon atmosphere at $600^{\circ} \mathrm{C}$ for 1 hour by pressing one-way as block-shaped samples under $700 \mathrm{MPa}$. The produced experiment specimens were characterized in terms of SEM (Scanning Electron Microscope), Optical microscope and micro hardness ( $\mathrm{HV}$ 0. 1) measurements. It was shown that aluminium matrix structure exhibited homogenous distribution depending on the increase in the volume ratio of $\mathrm{B}_{4} \mathrm{C}$ ve $\mathrm{SiC}$ ceramic particles; this was detected with microstructure images. According to the AA 2014 aluminum alloy, the hardness values were found to increase due to the increasing $\mathrm{SiC}$ and $\mathrm{B}_{4} \mathrm{C}$ ceramic particle reinforcement ratio. $\mathrm{In}_{4} \mathrm{C}-\mathrm{SiC}$ particle reinforced hybrid composite materials, the micro hardness value was relatively reduced compared to the single ceramic phase reinforcement containing $\mathrm{B}_{4} \mathrm{C} 15 \%$ ve $\% 15 \mathrm{SiC}$.
\end{abstract}

\section{GIRIŞ (INTRODUCTION)}

Kompozit malzemeler, yüksek rijitlik/yoğunluk ve mukavemet/yoğunluk oranlarına sahip ileri malzemelerin tasarımı ve üretimi açısından modern endüstride önemli bir yere sahiptirler. Sahip olduğu bu avantajlar, ağırlık ve mukavemetin çok önemli olduğu uzay ve havacılık gibi endüstrilerde, bu malzemelere geniş bir uygulama alanı oluşturmuştur. Bu malzemeler kullanıldıkları yapıların etkinliğini ve performansını önemli oranda artırmaktadır [1]. Pratikteki uygulamaların çoğunda, malzemenin 
mekanik özelliklerinin homojen ve izotropik olması istendiği için, parçacık takviyeli metal matrisli kompozitler ve genelde rastgele yönlenmiş takviye parçacıklar tercih edilmektedir [2].

Metal matrisli kompozitler (MMK) yüksek elastik modülü, yüksek çekme ve basma mukavemeti, metallerin süneklik ve tokluğunu, seramiklerin yüksek mukavemet ve yüksek elastik modül özelliklerini birleştirmelerinden dolayı, son derece önemli mühendislik malzemeleri haline gelmişlerdir [3]. Metal matrisli kompozit üretiminde, kompozitlerin mekanik özelliklerinin iyileştirilmesi amaçlı kullanılan yöntemlerin başında gelen parçacık takviyesi, oluşturulan kompozitin özelliklerini matrisin birkaç katına kadar çıkarabilmektedir. Genellikle parçacık takviyeli MMK malzeme üretiminde, döküm gibi sıvı hal yöntemleri olmasına rağmen, toz metalurjisi gibi bir katı hal yöntemi de tercih edilebilmektedir [4]. Günümüz teknolojik gelişmelerinin sunduğu avantajlar, birçok geleneksel üretim teknolojilerinin gelişimine yol açmaktadır. Ancak alışılagelmiş parça üretiminden daha teknolojik parça üretimine olan eğilim, dolayısıyla bu duruma paralel olarak toz metalurjisi teknolojisinin önemini giderek artırmaktadır. Özelliklede parçacık takviyeli metal matrisli kompozit malzeme üretim teknolojileri arasında toz metalurjisi tekniğinin giderek önem kazanmasına sebep olmaktadır [5]. Böylelikle toz metalurjisi yöntemi yüksek ergime derecesine sahip matrisler de dâhil olmakla birlikte, geniş bir çeşitlilikte matris takviye kompozisyonlarıyla üretimi olanaklı kılmaktadır [6].

Alüminyum ve alaşımları, MMK malzemeler içinde en çok talep gören matris malzemeleridir. $\mathrm{B}_{4} \mathrm{C}, \mathrm{SiC}$ ve $\mathrm{Al}_{2} \mathrm{O}_{3}$, alüminyum matrisli kompozitler içinde üzerinde en çok çalışılan takviye malzemeleridir. MMK sistemlerinde farklı matris-takviye kombinasyonları kullanılabilmektedir. Matris malzemeleri içinde alüminyum ve alüminyum alaşımları, düşük yoğunlukları, yüksek mukavemet ve tokluk değerleri, korozyon dirençleri ve kolay işlenebilirlikleri ile en çok tercih edilen malzeme grubunu oluşturmaktadır [6]. Alüminyum matris içerisinde kompozit malzeme oluşturmak için ilave edilen seramik parçacıkların en yaygın türleri arasında $\mathrm{Al}_{2} \mathrm{O}_{3}, \mathrm{SiC}$ ve $\mathrm{B}_{4} \mathrm{C}$ bulunmaktadır ve alüminyumun matris yapı içerisine ilave edilen bu seramik parçacıklar MMK'lerin gelişmesinde anahtar bir rol oynamıştır [7]. Hibrit metal matrisli kompozitler ise iki veya daha fazla birbirinden farklı takviye elemanının bir arada bulunduğu, kullanılan takviye elemanlarının avantajlarından yararlanmak için bir araya getirilmiş mühendislik malzemelerinin bir türünü oluşturmaktadır [7]. Hibrit kompozit malzemelerin, uzay ve havacılık sanayinde kullanımı başta hafiflik ve sağlamlık nitelikleri sayesindedir.

Özellikle titreşim, yorulma ve 1sı dayanımı gibi nitelikler, uzay ve havacılık sanayinde hibrit kompozit malzemelerin önde gelen avantajlarıdır. Hibrit kompozitler hafif kara, su ve hava taşımacılığı yapısal araçları, spor malzemeleri, hafif ve ortopedik elemanlarda kullanımı giderek artmaktadır. Hibrit yapılar oldukça geniş bir alanda malzeme tasarımına imkân sunmaktadır $[1,7,8,9]$. Dolayısıyla metal matrisli kompozit malzemelere kıyasla, mühendislik uyuglamalarında iyilişterilmiş mekanik özellikler ve yeni malzeme talebine olan ihtiyaçlar doğrultusunda aluminyum hibrit kompozit malzemeleri, iki veya daha fazla takviye fazlarının kombinasyonu ile sağlanan malzeme performansları açısından, tatmin edici mühendislik malzemeleri olarak giderek önem kazanmaktadır [10].

Bu çalışmada, AA 2014 aluminyum alaşımı metal matris yapısında farklı seramik parçacık takviye hacim oranlarında, toz metal deney numuneleri üretilmiştir. Özellikle uygulamalarda çoğunlukla yer alan, tek faz parçacık takviyesinin yanı sıra $\mathrm{B}_{4} \mathrm{C}$-SiC birlikteliğinde hibrit kompozit malzemelerinin mikroyapısal karakterizasyonu ve sertlik sonuçları üzerindeki farklılıkları incelenmiştir.

\section{MALZEME ve METOT (MATERIAL and METHOD)}

Deneysel çalışmalarda toz metal numune üretimi açısından başlangıç malzemesi olarak kullanılan AA 2014 aluminyum metal matris yapısı $(90,66 \mu \mathrm{m}$, gaz atomize) kimyasal bileşimi Çizelge 1'de verilmiştir. Kompozit ve hibrit kompozit yapılarının üretilmesinde kullanılan parçacık takviye elamanları $\mathrm{B}_{4} \mathrm{C}(5 \mu \mathrm{m}$, Aldrich) ve $\mathrm{SiC}$ (40 $\mu \mathrm{m}$, Aldrich) fiziksel özellikleri ise Çizelge 2’ de gösterilmiştir. 
Çizelge 1. AA 2014 alaşımının kimyasal kompozisyonu (Chemical composition of AA 2014 alloy)

\begin{tabular}{llllllllll}
\hline İçerik & $\mathrm{Al}$ & $\mathrm{Cu}$ & $\mathrm{Si}$ & $\mathrm{Mn}$ & $\mathrm{Mg}$ & $\mathrm{Fe}$ & $\mathrm{Zn}$ & $\mathrm{Cr}$ & $\mathrm{Ti}$ \\
\hline Ağırlıça \% & 93.5 & 4.06 & 0.6 & 0.57 & 0.56 & 0.47 & 0.106 & 0.03 & 0.01 \\
\hline
\end{tabular}

Çizelge 2. $B_{4} C$ ve SiC tozlarının fiziksel özellikleri (Physical properties of $B_{4} C$ and $\mathrm{SiC}$ powders)

\begin{tabular}{llllll}
\hline $\begin{array}{l}\text { Takviye } \\
\text { Malzemesi }\end{array}$ & $\begin{array}{l}\text { Yoğunluk } \\
\left(\mathrm{g} / \mathrm{cm}^{3}\right)\end{array}$ & $\begin{array}{c}\text { Isıl } \\
\text { Genleşme } \\
\text { Katsay1s1 } \\
\left(10^{-6} \mathrm{~K}^{-1}\right)\end{array}$ & $\begin{array}{l}\text { Ergime } \\
\text { Sicakl }{ }^{\circ} 1 \\
\left(0^{\circ} \mathrm{C}\right)\end{array}$ & $\begin{array}{l}\text { Mukavemet } \\
(\mathrm{MPa})\end{array}$ & $\begin{array}{l}\text { Elastiklik } \\
\text { Modülü (GPa) }\end{array}$ \\
\hline $\mathrm{B}{ }_{4} \mathrm{C}$ & 2.52 & 6.08 & 2420 & 2759 & 448 \\
\hline $\mathrm{SiC}$ & 3.16 & 4.8 & 1800 & 700 & 400 \\
\hline
\end{tabular}

Presleme çalışmalarında toz metal deney numunelerinin üretilmesi bakımından, hazırlanan matris ve takviye parçacıklarının, farklı hacim oranları ve miktarları Çizelge 3' de gösterilmiştir. Her bir numune grubundan 3 adet olmak üzere, 24 adet deney numunesi çalışmalarda kullanılmıştır. Çalışmada seçilen en düşük ve yüksek hacimsel oranların merkezinde olması sebebiyle, özellikle $\% 10$ hibrit kompozit malzeme hacim oranı belirlenmiştir. Tek faz seramik takviyesi ile üretilen kompozit malzemelerin, mikro yapı ve mekanik özellikleri ile karşılaştırılmıştır. Matris ve takviye başlangıç tozlarının karıştırma işlemi, Fritsch model planetary tip cihaz kullanılarak, 30 dakika süreyle gerçekleştirilmiştir.

Çizelge 3. Deney numunelerinin içerik ve bileşimleri (Contents and composition of test samples)

\begin{tabular}{lllll}
\hline Numuneler & AA2014 (\%) & $\mathrm{B}_{4} \mathrm{C}(\%)$ & $\mathrm{SiC}(\%)$ & Ağrllik (gram) \\
\hline AA & 100 & & & 2 \\
\hline AB5 & 95 & 5 & & $1.9+0.1$ \\
\hline AB10 & 90 & 10 & & $1.8+0.2$ \\
\hline AB15 & 85 & 15 & 5 & $1.7+0.3$ \\
\hline AS5 & 95 & & 10 & $1.9+0.1$ \\
\hline AS10 & 90 & & 15 & $1.8+0.2$ \\
\hline AS15 & 85 & & 10 & $1.6+0.3$ \\
\hline ABS10 & 80 & 10 & & \\
\hline
\end{tabular}

Çizelge 3' de belirtilen matris ve seramik parçacık takviye elamanlarının, parçacık hacim oranları ve miktarlarına bağlı olarak, hazırlanan toz karışımları Şekil 1-a' da gösterilen kalıp içerisinde, tek yönlü olarak 700MPa basınç altında preslenmişlerdir. Böylece matris/takviye toz karışımları, silindirik/blok numuneler (12 mm çap ve $10 \mathrm{~mm}$ yükseklik) şekline dönüştürülmüştür. Presleme işlemi sonrası deney numuneleri, atmosfer kontrollü ısıl işlem firını kullanılarak, cam tüp içerisinde argon gazı akışı altında $600^{\circ} \mathrm{C}$ sicaklıkta 1 saat sinterlenmiştir. Presleme işlemini takiben, sinterleme işlemi öncesi ve sonrası deney numunelerinin görünümü, Şekil 1-b ve c' de gösterilmiştir.

Toz metalurjisi yöntemi kullanılarak üretilen deney numunelerinin sinterleme işlemi ve öncesi yoğunluk ölçümleri, Kern marka hassas terazi $(0,0001)$ kullanılarak, numuelerin ağırılıkları tespit edilmiş, Micrometrics marka piknometre ile yoğunluk ölçümleri gerçekleştirilmiştir. Bu yöntemde Bu Deney numunelerinin mikroyapısal karakterizasyonu bakımından, sirasıyla zımparalama (600-800-1200 zımpara), parlatma ( $1 \mu \mathrm{m}$ elmas pasta) ve dağlama $(95 \mathrm{ml} \mathrm{H} 2 \mathrm{O}$ ve $5 \mathrm{ml} \mathrm{HCl})$ işlemleri olmak üzere, genel metalografi çalışmaları yapılmıştır. 
Üretilen kompozit ve hibrit kompozit yapıları içerisinde, $\mathrm{B}_{4} \mathrm{C}$-SiC parçacıklarının dağılımlarının belirlenmesi amac1yla, optik mikroskop (Hardway marka) ve Hitachi SU 1510 model, taramalı elektron mikroskobu (SEM) çalışmalarda kullanılmıştır. Üretimi gerçekleştirilen saf deney numunelerine kıyasla, kompozit ve hibrit kompozit numunelerinin farklı parçacık hacim oranlarına bağlı olarak sertlik ölçümleri, Hardway marka mikro sertlik cihazı (HV0.1) kullanılarak gerçekleştirilmiştir.

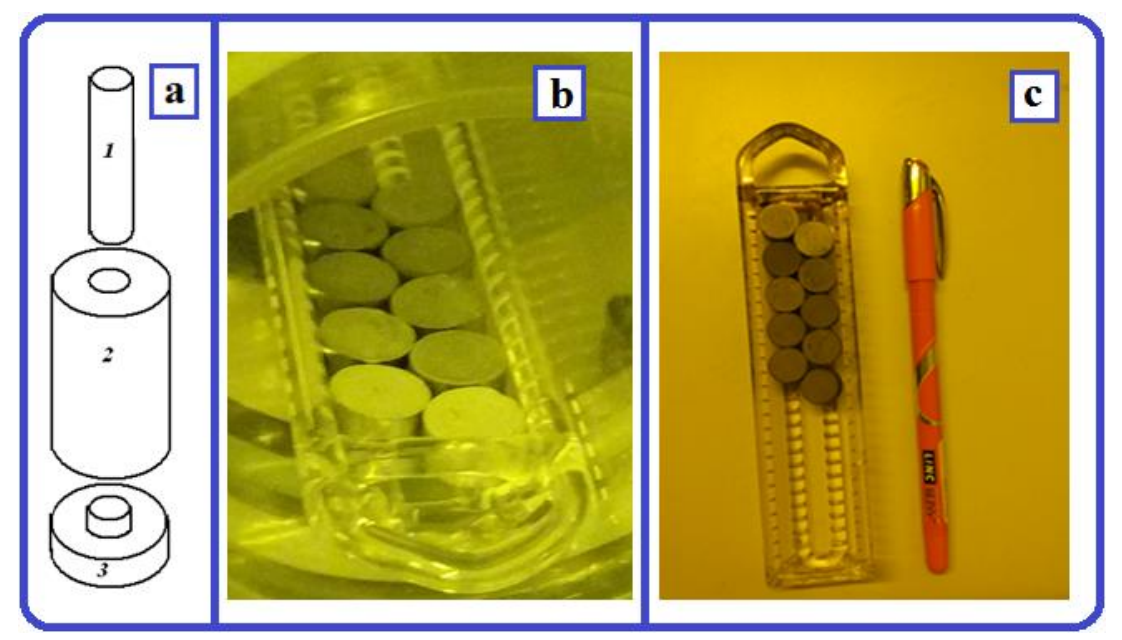

Şekil 1. Deney numunelerinin sinterleme öncesi ( $a-b)$ ve sonrası (c) görünümleri

(The pre-sintering ( $a-b)$ and post-sintering $(c)$ views of the test specimens)

\section{SONUÇLAR ve TARTIŞMA (RESULTS and DISCUSSION)}

Toz metal deney numunelerinin üretilmesinde kullanılan, matris ve takviye elemanlarının SEM görüntüleri Şekil 2' de verilmiştir. Şekil 2' deki SEM görüntüleri incelendiğinde, gaz atomize AA 2014 aluminyum alaşımının, çoğunlukla küresel ve küresele yakın toz tanelerinden oluştuğu görülmektedir. $\mathrm{B}_{4} \mathrm{C}$ seramik faz parçacıklarının ise düzensiz şekil morfolojisinde ve aynı zamanda düşük parçacık boyutu ile topaklanma eğiliminde olduğu mikro yapı görüntüsü ile tespit edilmiştir. Özellikle hibrit kompozit malzeme üretiminde önemli olan bir diğer $\mathrm{SiC}$ seramik faz parçacıklarının ise, küresel şekline yakın olduğu ve çoğunlukla poligonal keskin köşeli şekil morfolojisine sahip olduğu belirlenmiştir.

Üretimi gerçekleştirilen metal matrisli kompozit ve hibrit kompozit deney numunelerinin sinterleme öncesi ve sonrası hacim hesabı prensibine göre hesaplanan yoğunluk ölçüm sonuçları Şekil 3' te verilmiştir. Presleme işlemi ile sonrası (kompozit ve hibrit kompozit) deney numunelerinin yoğunluk değerleri, Aluminyum malzemesinin yoğunluk değeri olan yaklaşı $2.75 \mathrm{~g} / \mathrm{cm}^{3}$ değerine yakınlaştırılmaya çalışılmıştır. Presleme işlemi sonrası deney numunelerinin ham yoğunluk değerleri (Figure 3,0), yaklaşık olarak $2.68 \mathrm{~g} / \mathrm{cm}^{3}$ olarak tespit edilmiştir ve sinterleme sonrası saf AA 2014, kompozit ve hibrit kompozit malzeme yoğunluk değerleri ile karşılaştırılmıştır (Şekil 3). 


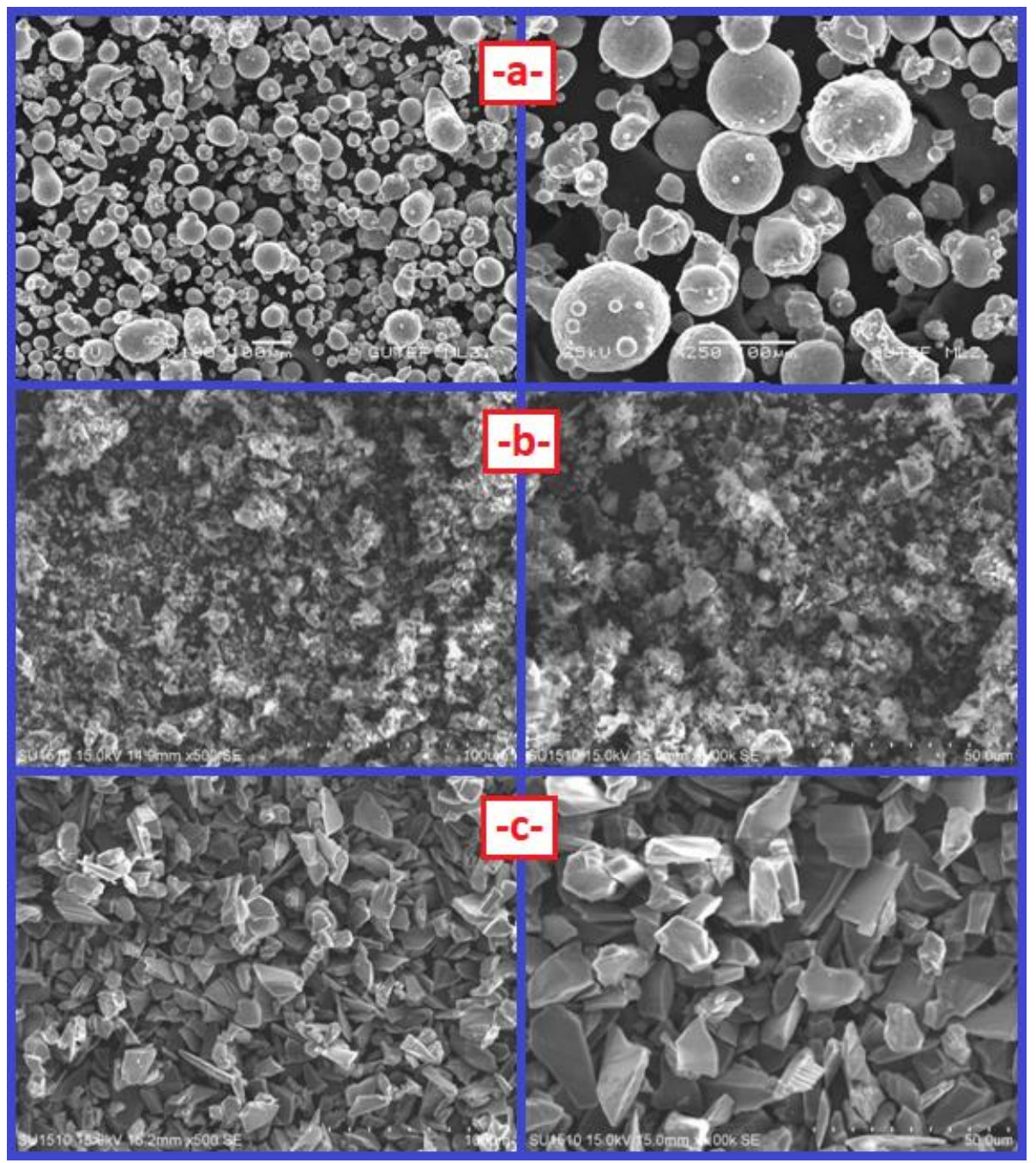

Şekil 2. Matris ve takviye tozlarının SEM görüntüleri; a) AA 2014, b) $B_{4} C$ ve c) SiC (SEM images of matrix and reinforcement powders; a) $A A 2014, b) B_{4} C$ and c) $\mathrm{SiC}$ )

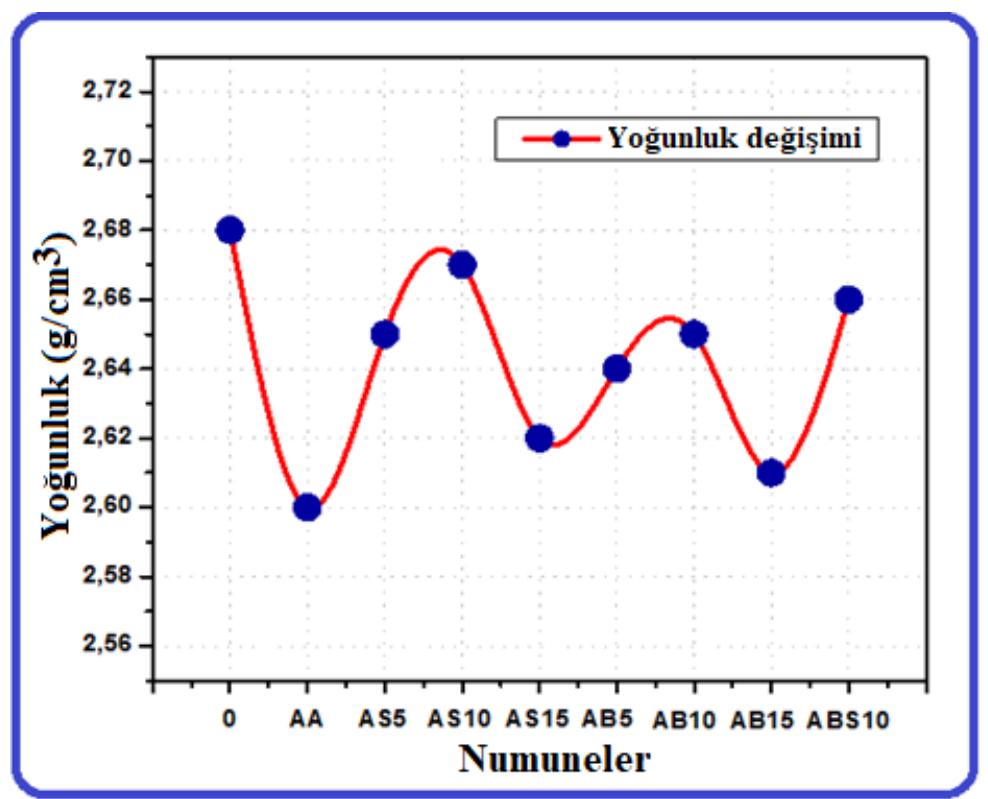

Şekil 3. Deney numunelerinin sinterleme öncesi (0) ve sonrası yoğunluk değişimleri (The density changes of the test specimens before (0) and after sintering) 
Özellikle Gökmeşe ve ark.' nın AA 2014 matris malzemesi için yapılan farklı presleme basınçlarında [11] AA 2014 alaşımı ve elde edilen yoğunluk değerleri incelendiğinde, yoğunluk artışı düşük basınçlarda önce hızlıdır, fakat gözenekler kapandıkça toz, yoğunlaşmaya karşı artarak direnç gösterir. Çok tabidir ki parçacık sertliği sıkıştırma için önemli bir parametredir [12]. Bu bağlamda belirlenen optimum presleme basınc1 olan $700 \mathrm{MPa}$ altında presleme işlemi sonrası uygulanan sinterleme işlemi ile, AA 2014 aluminyum alaşımı, kompozit ve hibrit kompozit deney numunelerinin yoğunluk değerlerinde bir azalma olduğu tespit edilmiştir (Şekil 3). Yoğunluk değerinde önemli bir azalma, 2,60 g/ $\mathrm{cm}^{3}$ olarak saf AA 2014 aluminyum alaşımında tespit edilmiştir. Benzer bir şekilde presleme sonrası sinterleme işlemi ile azalan yoğunluk değeri, kompozit ve hibrit kompozit malzemelerinde de tespit edilmiştir. Ayrıca üretilen kompozit/hibrit malzemelerinin nispi (\%) yoğunluk değerlerinin karşılaştırması da Şekil 4' te gösterilmiştir. Özellikle hibrit kompozit malzemesinde yoğunluk değerinin, \%10 seramik faz takviyeli kompozit malzeme yoğunluk değerlerine yakın olduğu tespit edilmiştir. Toz metal deney numunelerinin yoğunluk değerlerinde ortaya çıkan azalma üzerinde etkili olan durumun, AA 2014 aluminyum alaşımı matris malzemesi ile seramik parçacıkları bağlanma/ara yüzeylerinde görülen boşluklardan kaynaklı olduğu belirtilebilir. Parçacık miktarındaki artışa bağlı olarak ara yüzeyde gözlenen boşluk miktarının $\operatorname{arttığ1~ve~bu~duruma~paralel~olarak~yoğunluğun~azaldığı~belirtilebilir~[7].~Ayrıca~AA~} 2014$ aluminyum alaşımlı matris yapısı içerisinde yer alan temel alaşım elementi bakırın, sinterleme esnasında meydana gelen şişme etkisinden dolayı, gözeneklerin küçülmesine karşı koyarak, yoğunluk artışı önüne geçmesi, bir diğer önemli etkileşim olarak gösterilebilir [12].

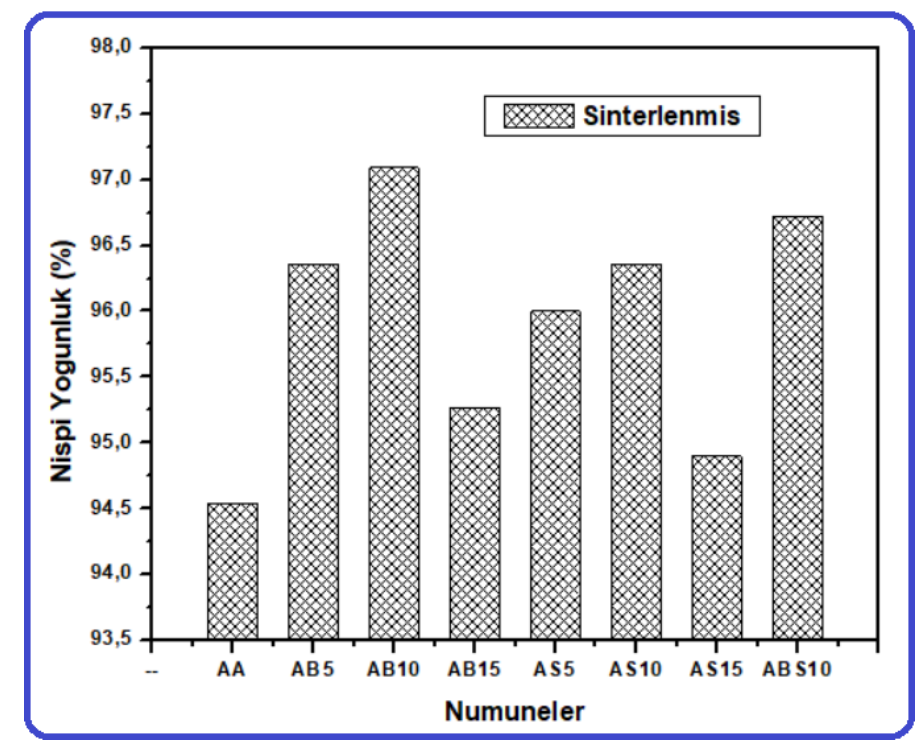

Şekil 4. Deney numunelerinin sinterleme sonrası nispi yoğunluk değişimleri (Relative density changes after sintering of the test specimens)

Presleme işlemini takiben, uygulanan $600^{\circ} \mathrm{C}^{\prime}$ de 1 saat sinterleme işlemi sonucu, matris AA 2014 aluminyum alaşımı, takviye elamanları artışına bağlı olarak elde edilen metal matrisli kompozit ve hibrit kompozit deney numunelerinin, mikro yapı görüntüleri sırasıyla Şekil 5, 6 ve 7' de gösterilmiştir. Matris AA 2014 aluminyum alaşımının düşük ve yüksek büyütmedeki optik mikroskop görüntüleri incelendiğinde (Şekil 5, sarı-yuvarlak şekil), tane yapısı-gözenek ilişkisi bakımından özellikle tane sınırlarında ve tanelerin temas noktalarındaki birleşmeden kaynaklı olarak ortaya çıkan küresel ve küresele yakın gözenek etkileşimleri açısından [13] sinterleme pratiğinin yeterli olduğu belirtilebilir. Benzer durumun sırasıyla Şekil 6 ve 7' da, \%5-10-15 SiC ve \%5-10-15 $\mathrm{B}_{4} \mathrm{C}$ seramik parçacık takviyeli kompozit malzemelerinde olduğu belirtilebilir. 


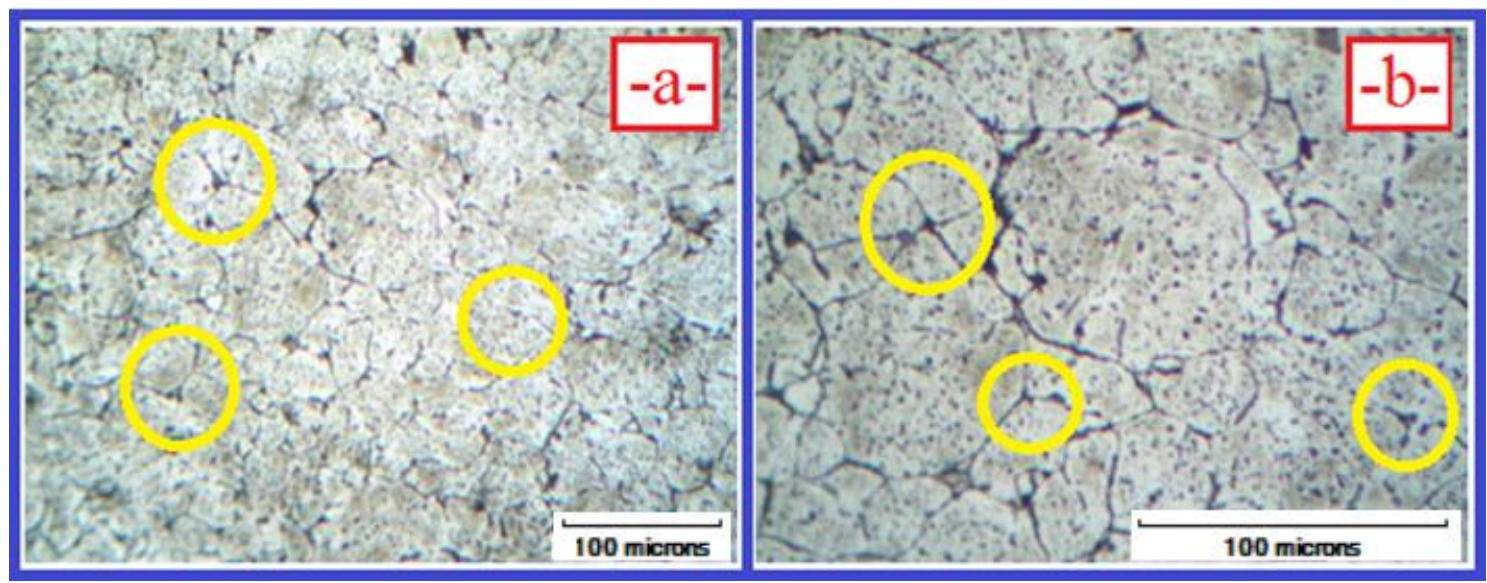

Şekil 5. Matris AA 2014 alumiyum alașımı (a) ve (b); $600{ }^{\circ} \mathrm{C}$-1 saat sinterleme (Matrix AA 2014 aluminum alloy (a) and (b); $600{ }^{\circ} \mathrm{C}-1$ hour sintering)

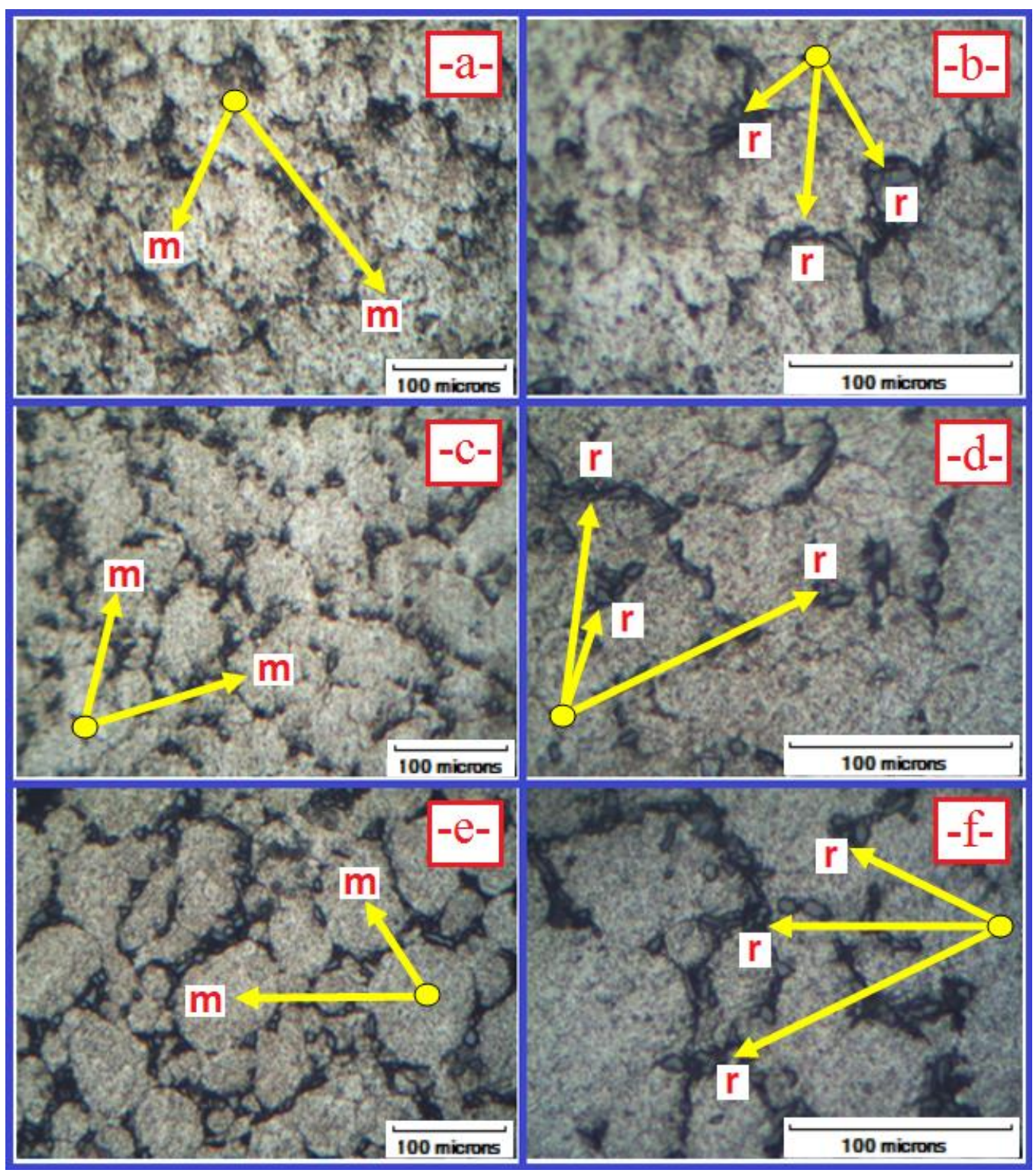

Şekil 6. $600^{\circ} \mathrm{C}-1$ saat sinterleme sonrası mikro yapı görüntüleri;

(a) AA2014-\%5 SiC, (b) AA2014-\%10 SiC ve (c) AA2014-\%15 SiC (Microstructure images after sintering at $600^{\circ} \mathrm{C}-1$ hour;

(a) AA2014 - 5\% SiC, (b) AA2014 - 10\% SiC and (c) AA2014 - 15\% SiC) 


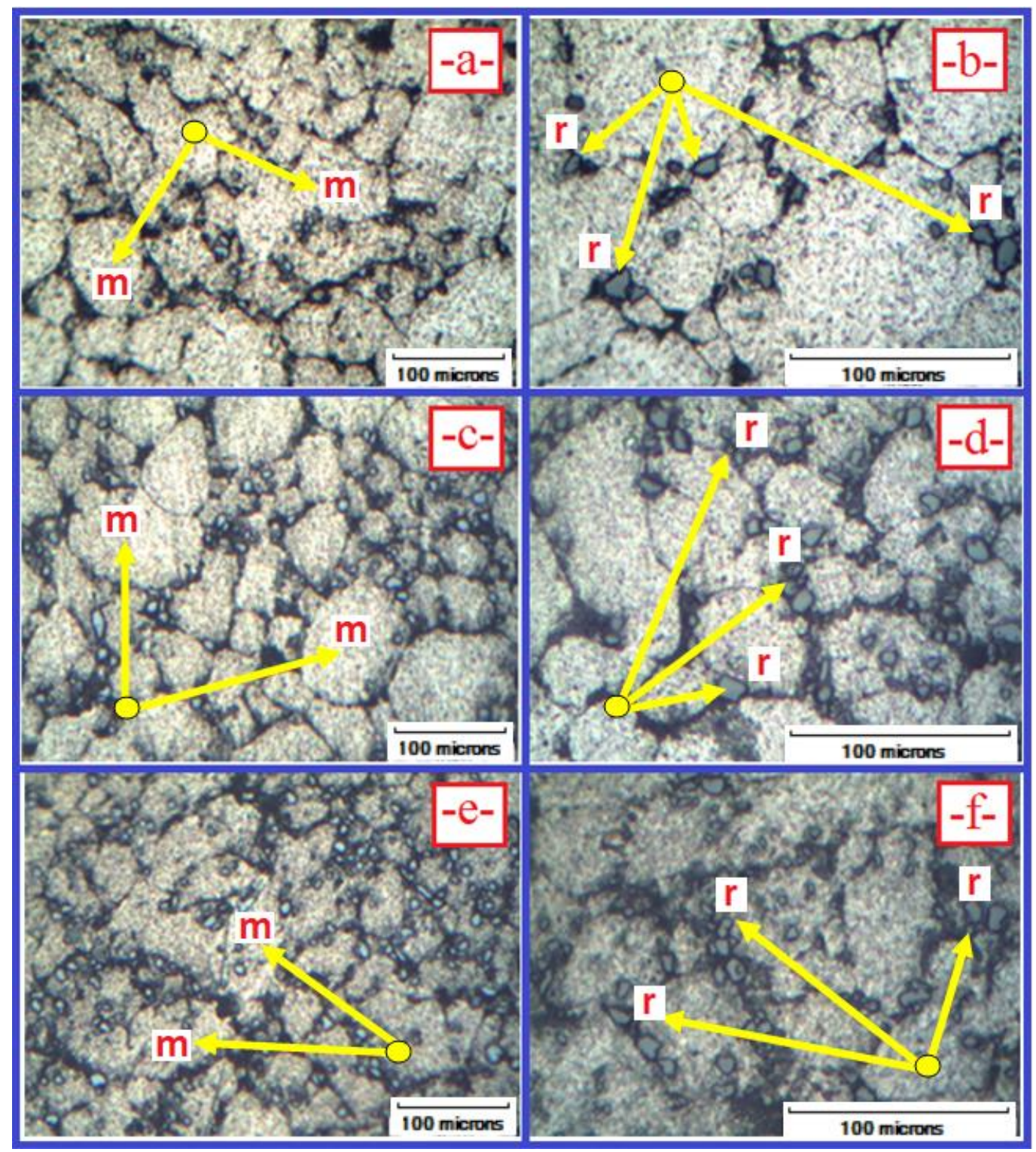

Şekil 7. $600^{\circ} \mathrm{C}-1$ saat sinterleme sonrası mikro yapı görüntüleri;

(a) AA2014-\%5 B $B_{4} C$, (b) AA2014- \%10 B ${ }_{4} C$ ve (c) AA2014-\%15 B ${ }_{4} C$

(Microstructure images after sintering at $600^{\circ} \mathrm{C}-1$ hour;

(a) $A A 2014-5 \% B_{4} C$, (b) $A A 2014-10 \% B 4 C$ and (c) $A A 2014-15 \% B_{4} C$ )

Şekil 6 ve $7^{\prime}$ de gösterilen metal matrisli kompozit numunelerinde, $\mathrm{SiC}$ ve $\mathrm{B}_{4} \mathrm{C}$ seramik parçacık takviyesi hacim oranındaki artışa bağlı olarak, matris (matrix-m) / takviye (reinforcement-r) ara yüzey ve dağılımları, mikro yapı görüntüleri ile açık bir şekilde görülmektedir. Düşük seramik faz parçacık takviyesine bağlı olarak, matriste nispeten dağılımın az olduğu belirtilebilir (Şekil 6, 7b-d). Ancak seramik faz parçacık hacim oranındaki artı̧̧a bağlı olarak, özelikle \%15 SiC (Şekil 6-e ve f) ve \% $15 \mathrm{~B}_{4} \mathrm{C}$ (Şekil 7-e ve f) hacim oranında, seramik parçacık takviye fazlarının homojen bir şekilde dağılımında olduğu belirtilebilir. Şekil 6' daki mikro yapı görüntüleri incelendiğinde, SiC seramik faz parçacıklarına nazaran, aluminyum matris yapısında $\mathrm{B}_{4} \mathrm{C}^{\prime}$ nin daha homojen ve uyumlu bir dağılım gösterdiği söylenilebilir. Ancak hem $\mathrm{SiC}$ hem de $\mathrm{B}_{4} \mathrm{C}$ seramik faz parçacık takviyelerinin, özellikle artan takviye hacim oranına bağlı olarak, tane sınırı ve tane sınırına yakın olan bölgelerde, yoğunlaşmaların olduğu söylenebilir. Dolayısıyla ortaya çıkan bu durum hem presleme hem de sinterleme çalışmalarında tam yoğunluklu malzeme üretim sürecinde önemli bir etkiye sahip olabilmektedir. 


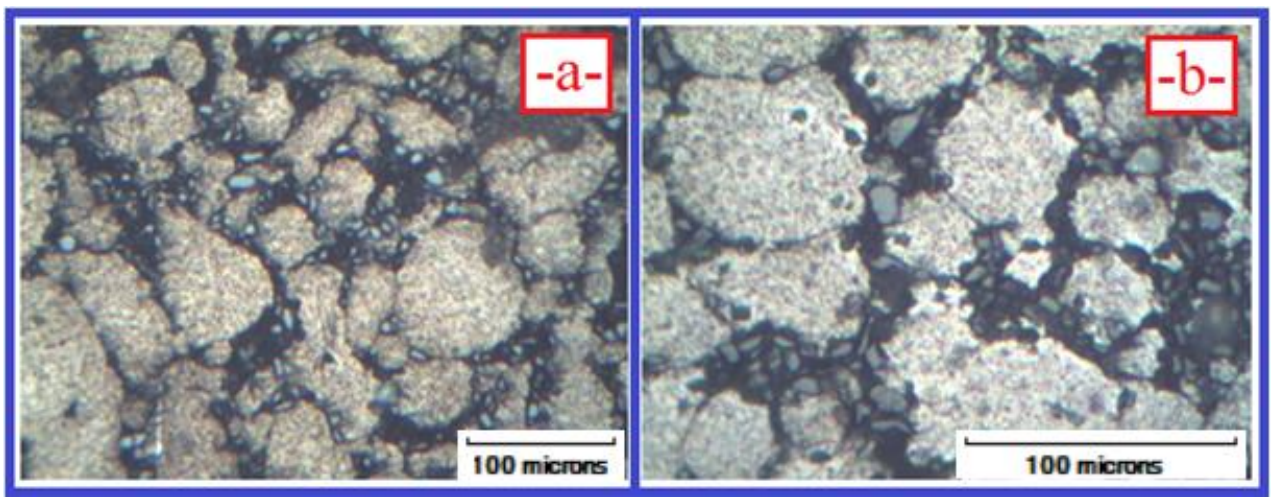

Şekil 8. $600^{\circ} \mathrm{C}-1$ saat sinterleme sonrası mikro yapı görüntüleri;

(a) ve (b) $\mathrm{AA2014- \% 10B}{ }_{4} \mathrm{C}-\% 10 \mathrm{SiC}$

(Microstructure images after sintering at $600^{\circ} \mathrm{C}-1$ hour;

(a) and (b) $\mathrm{AA} 2014-10 \% \mathrm{~B}_{4} \mathrm{C}-10 \% \mathrm{SiC}$ )

Özellikle toz metal kompozit malzeme üretim teknolojilerinde [14-16], tane ve tane sınırlarına yakın bölgelerde dağılım gösteren takviye elamanları, özellikle gözeneklerin küçülmesine karşı koyabilmekte dolayısıyla gerek malzeme mekanik özellikleri gerekse malzeme performansı bakımından etkili olabilmektedir. Çift faz seramik parçacık takviyesinin (\%10B $\left.{ }_{4} \mathrm{C}-\% 10 \mathrm{SiC}\right)$, AA 2014 aluminyum metal matris yapısında dağılımı ile üretimi gerçekleştirilen hibrit kompozit malzemesinin, mikro yapı görüntüleri Şekil 8 ve 9' da gösterilmiştir. Şekil 8' deki mikro yapı görüntüleri incelendiğinde, hibrit kompozit deney numunesinde, parçacık takviyelerinin homojen bir şekilde dağılım gösterdiğinden bahsedilebilir. Ancak seramik parçacık takviye fazlarının matris ile temasında bazı bölgelerde yoğun bir şekilde yer aldığ numunelerinin Şekil 9' daki SEM görüntüleri ile, oksit oluşumları ve dağılımlarının mikro yapıda yer aldığı görülmektedir. Bu durumun malzeme mikro yapı hazırlık aşamasında ve metalografi çalışmaları sonrası deney numuneleri yüzeyinde ortaya çıktığı belirtilebilir. Mikro yapı görüntüleri doğrultusunda, özellikle seramik faz parçacıkların çoğunluğunun, tane sınırlarında dağılım oluşturduğu anlaşılmaktadır. AA 2014 alumimyum metal matris yapısında, $\mathrm{SiC}$ ve $\mathrm{B}_{4} \mathrm{C}$ seramik faz parçacıklarının takviyesi ile üretilen hibrit kompozit malzemesinde malzeme mikroyapısı olarak, elementel dağılım haritalaması yapılmıştır (Şekil 10). AA 2014 alaşımında bulunan Al ve temel alaşım elementi olan Cu' nun; çoğunlukla matris yapısı olarak yer aldığı, numune yüzeyinde ortaya çıkan oksit dağılımının; $O$ ile temsil edildiği, SEM mikro yapı görüntüsü bölgesel farklılıkları üzerinden anlaşılmaktadır. Özellikle seramik faz parçacıkların, mikroyapıda yer aldığı bölgeler ve dağılımları açısından; $\mathrm{Si}, \mathrm{C}$ ve B elementleri dağılımları incelenmiştir.

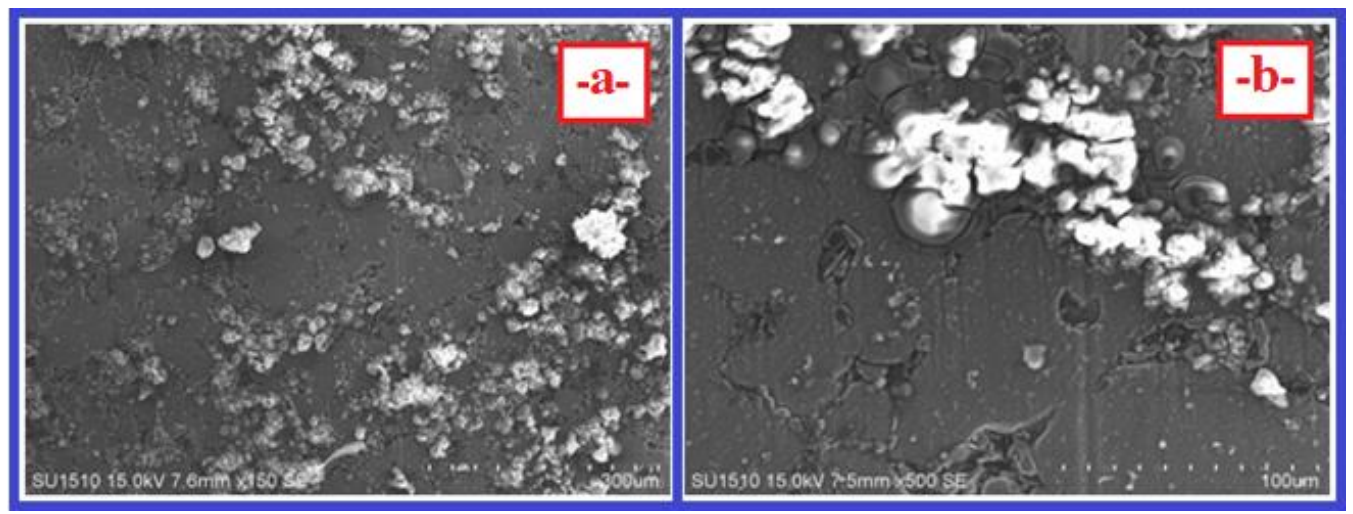

Şekil 9. $600^{\circ} \mathrm{C}-1$ saat sinterleme sonrast SEM mikro yapı görüntüleri; (a) ve (b) AA2014-\%10B ${ }_{4} \mathrm{C}-\% 10 \mathrm{SiC}$

(SEM microstructure images after sintering at $600^{\circ} \mathrm{C}-1$ hour; (a) and (b) $\mathrm{AA} 2014-10 \% \mathrm{~B}_{4} \mathrm{C}-10 \% \mathrm{SiC}$ ) 


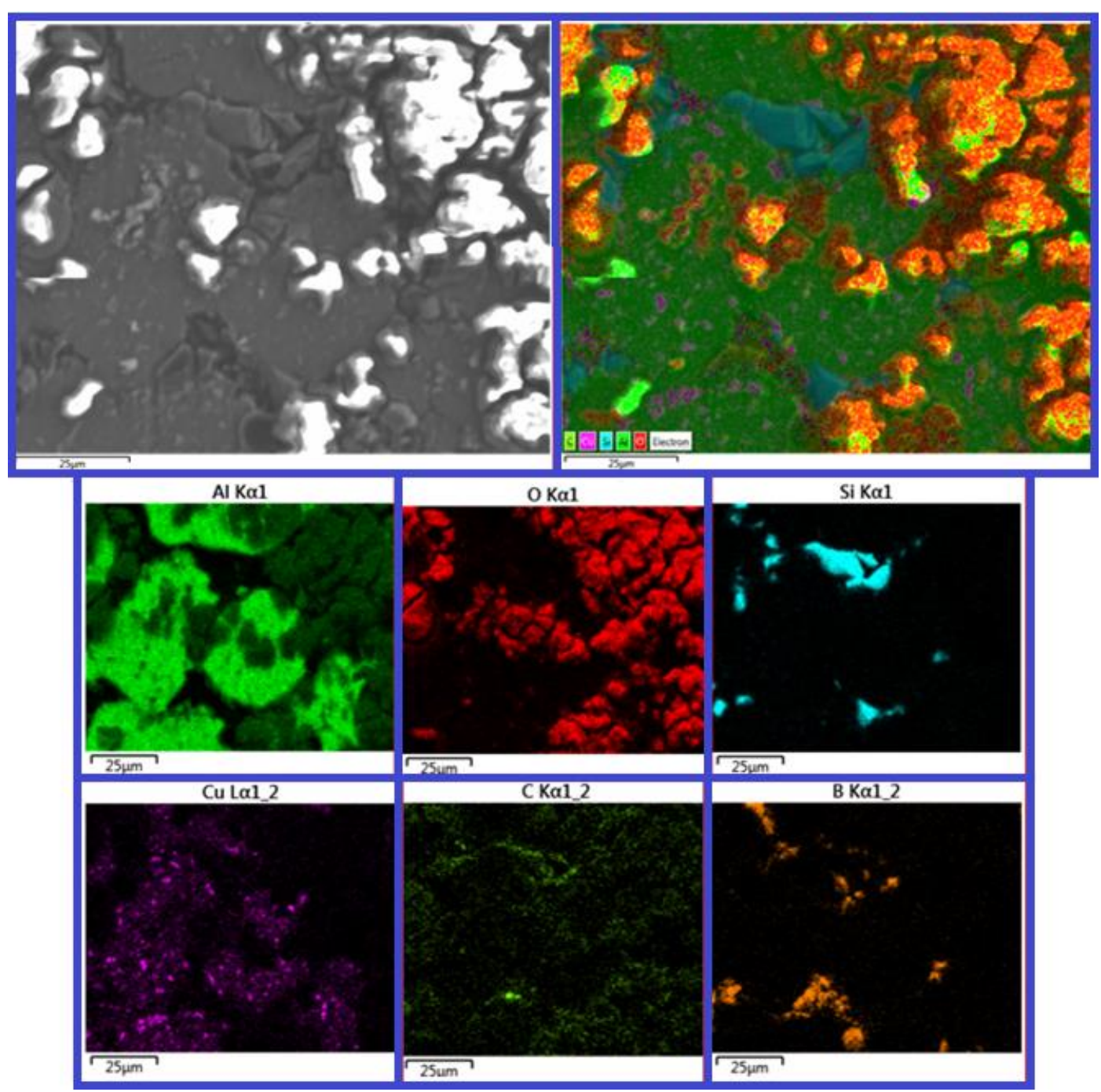

Şekil 10. AA2014-\%10B ${ }_{4} C$-\%10SiC hibrit kompozit malzemesinin, elementel dağılım haritalamast

(The elemental distribution mapping of AA2014-10\% $B_{4} C-10 \%$ SiC hybrid composite material)

Böylece bu elementler üzerinden, $\mathrm{SiC}$ ve $\mathrm{B}_{4} \mathrm{C}$ takviye fazlarının sergilediği dağılımları ve mikroyapısal olarak ortaya çıkan farklılıkları açık bir şekilde görülebilmektedir. Şekil 10 da, AA 2014 aluminyum matris içerisinde, $\mathrm{SiC}$ ve $\mathrm{B}_{4} \mathrm{C}$ seramik faz takviye parçacıklarının dağılımını gösteren SEM resmi, genel ve nokta EDS analiz değerleri verilmiştir. Hibrit kompozit malzemesinin Şekil 10' da verilen EDS analizi sonuçları incelendiğinde, Map Sum Spectrum ile gösterilen genel EDS analizinin yanı sıra dört farklı bölgeden alınan Spectrum 5-8 nokta EDS analizi sonuçları görülmektedir. Spectrum 5 ve 7' de yapılan nokta analizi sonucuna göre, özellikle tane sınırlarında dağılım gösteren daha küçük ve düzensiz şekilli parçacıkların, $\mathrm{B}_{4} \mathrm{C}$ seramik fazını tanımladığı anlaşılmaktadır. Spectrum 6' da yapılan nokta analizi sonucuna göre, Si elementinin ağırlıkça yüzdesi bakımından, daha iri taneli ve poligonal şekline sahip parçacıkların, SiC seramik fazını temsil ettiği belirtilebilir. Ayrıca Spectrum 8' de yapılan nokta analizi sonucuna göre, tane içinde bir bölgeden alınması sebebiyle matris yapısının yani AA 2014 alaşımı kimyasal bileşenlerini tanımladığı görülebilmektedir. Böylece hibrit kompozit malzemesinde, gerek elementel dağılım haritalaması gerekse EDS nokta analizi sonuçlarına göre, $\mathrm{SiC}$ ve $\mathrm{B}_{4} \mathrm{C}$ seramik faz takviye parçacıklarının, çoğunlukla tane sınırlarında kümelendiği belirtilebilir. 


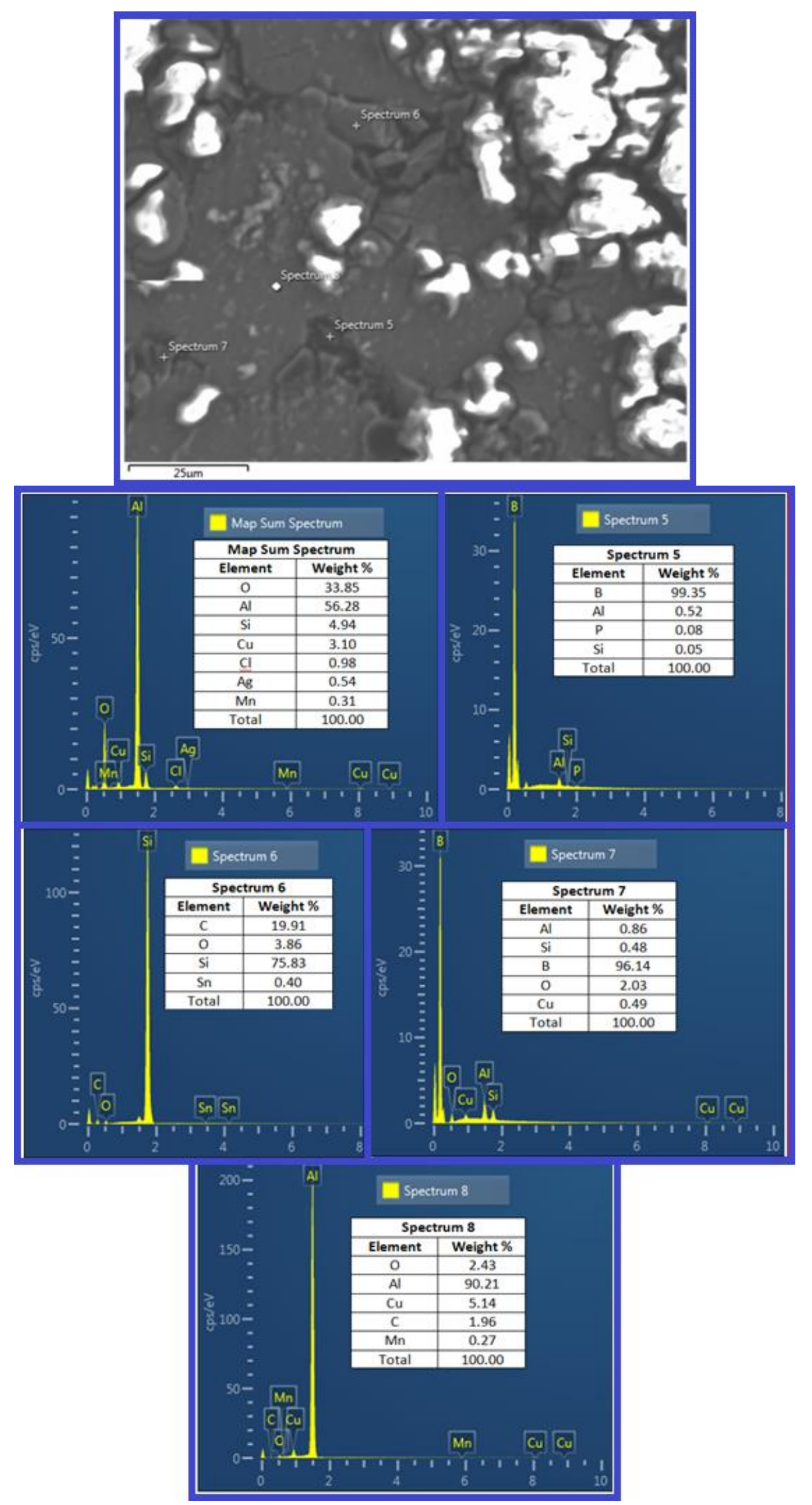

Şekil 11. AA2014-\%10B 4 C-\%10SiC hibrit kompozit malzemesinin EDS analiz sonuçları (EDS analysis results of AA2014-\% 10B4C-\% 10SiC hybrid composite material) 
Şekil 12' de AA2014 aluminyum alaşımı, kompozit ve hibrit deney numunelerinin mikro yap1 incelemeleri neticesinde, elde edilen mikro sertlik sonuçları gösterilmiştir. Şekil 12' de verilen mikro sertlik sonuçları incelendiğinde, en düşük sertlik sonucu 53HV olarak AA 2014 aluminyum alaşımında elde edilmiştir. Tek faz SiC seramik parçacık takviyesi ile edilen kompozit deney numunelerinde, parçacık hacim oranındaki artışa bağlı olarak sertlik değerlerinin artış gösterdiği tespit edilmiştir. Böylelikle bu kompozit numunelerde en yüksek sertlik değeri, \%15 SiC hacim oranında 77HV olarak ölçülmüştür. $\mathrm{SiC}$ seramik parçacık takviyesi ile elde edilen sertlik değerlerine benzer bir şekilde, $\mathrm{B}_{4} \mathrm{C}$ seramik parçacık takviyesi artışına bağlı olarak, mikro sertlik değerleri artış göstermiştir. En yüksek mikro sertlik değeri $\% 15 \mathrm{~B}_{4} \mathrm{C}$ hacim oranında $86 \mathrm{HV}$ olarak ölçülmüştür. $\mathrm{Bu}$ durumda $\% 15 \mathrm{~B}_{4} \mathrm{C}$ seramik parçacık takviyesi ile üretilen kompozit malzemede $\mathrm{SiC}^{\prime}$ e kıyasla, yaklaşık \%11' lik bir artış değeri tespit edilmiştir.

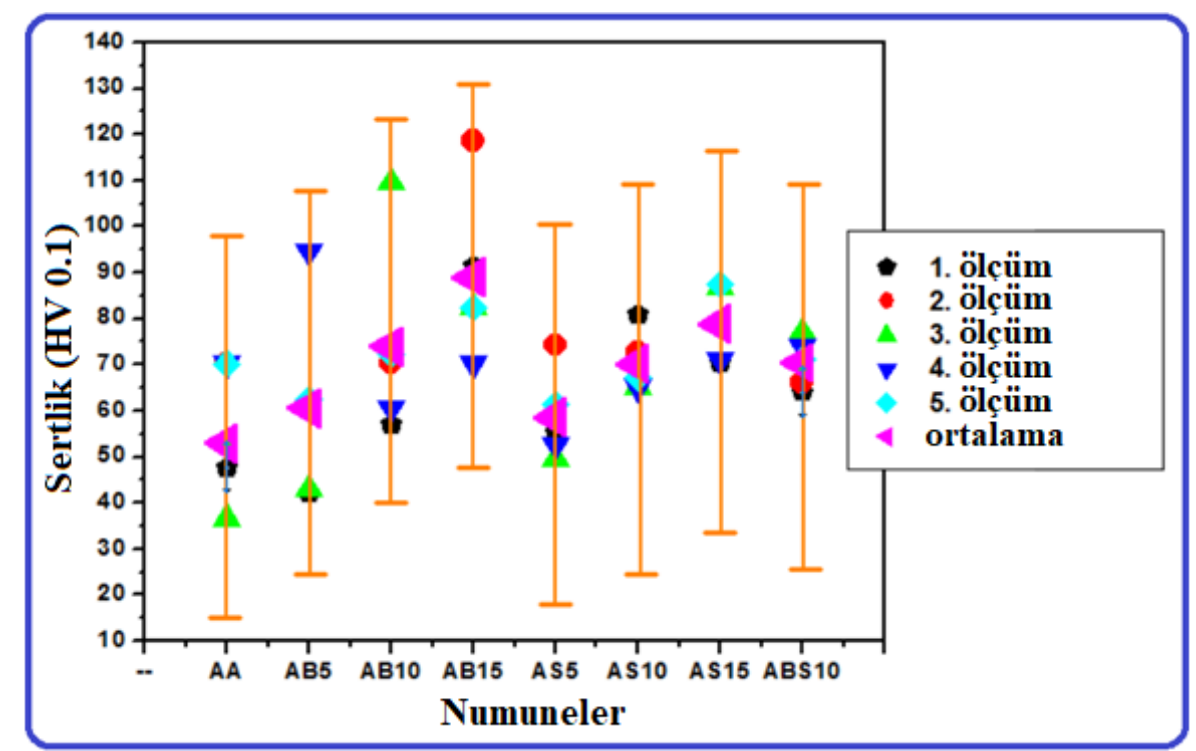

Şekil 12. AA2014/kompozit/hibrit numunelerde matrisin mikro sertlik değişimi

(Micro hardness change of matrix in AA2014 / composite / hybrid samples)

Eşit seramik faz parçacık hacim oranı ile üretilen hibrit kompozit numunelerinde, $68 \mathrm{HV}$ sertlik değeri ölçülmüştür. Kompozit deney numunelerine kıyasla mikro sertlik değerinde azalma olduğu tespit edilmiştir. $\mathrm{B}_{4} \mathrm{C}$ seramik parçacıklarının $\mathrm{SiC}$ seramik parçacıklarına kıyasla daha yüksek sertlik değeri sergilediği bilinmektedir [17, 18]. Bu bakımdan hibrit kompozit malzemesi yapısında eşit hacimde yer alan $\mathrm{SiC}$ seramik faz parçacıklarının sertlik değerinin azalmasında etkili olduğu belirtilebilir. Böylelikle kompozit malzeme özellikleri bakımından bir değerlendirme yapıldığında, artan takviye hacim oranına bağlı olarak yüksek sertlikteki tek faz takviyeli kompozit malzemelerine nazaran hibrit kompozit malzemelerinin, azalan ve orta seviyede bir sertlik değeri ön plana çıkmaktadır. Dolayısıyla bu tarzdaki hibrit kompozit malzemelerde, azalan sertlik değerine karşı artan bir süneklik değeri ile malzeme mekanik özellik kombinasyonları bakımından, malzeme seçimi, tasarımı ve uygulamalarında etkili olabileceği düşünülmektedir. Baradeswaran ve ark., aluminyum alaşımına yapılan grafit ilavesinin sertlik, çekme ve basma dayanımı değerlerini azaltırken, grafitin yanı sıra $\mathrm{Al}_{2} \mathrm{O}_{3}$ seramik faz takviyesi ile oluşturulan hibrit kompozit bünyede, belirtilen bu olumsuzlukların iyileştirilebildiğini vurgulamışlardır [19].

Takviyesiz alaşımlara kıyasla hibrit kompozit malzemelerinin, farklı korozif ortamlarda korozyon direncinin, iyi tribolojik ve mekanik özellikler sergilediği belirtilmektedir. Bunun yanı sıra hibrit takviye kullanıldığında, tek takviyeli malzeme üretimlerine göre, ne kadar gelişim sağlanabildiği karşılaştırılabilmektedir. Optimum işlem parametreleri altında yeni nesil hibrit kompozit malzemelerinin üretimi ile malzeme mikro yapı ve mekanik özellikleri geliştirilebilir ve optimize üretim süreçleri bu tarzdaki malzemelerde elde edilebilmektedir [10]. 


\section{SONUÇ (CONCLUSION)}

Yapılan çalışmada, ön alaşımlı AA 2014 aluminyum alaşımına kıyasla, metal matrisli kompozit ve hibrit kompozit malzemelerinin üretimleri gerçekleştirilmiştir. Presleme ve sinterleme işlemleri sonrası elde edilen sonuçlar aşağıda sunulmuştur;

Ön alaşımlı AA 2014 aluminyum alaşımı, $\mathrm{SiC}$ ve $\mathrm{B}_{4} \mathrm{C}$ seramik faz parçacıkları takviye hacim oranları artışına bağlı olarak, kompozit ve hibrit kompozit malzemelerinin, sinterleme sonrası yoğunluk değerleri azalmıştır. AA 2014 metal matris yapısında, artan $\mathrm{SiC}$ ve $\mathrm{B}_{4} \mathrm{C}$ seramik faz parçacık takviyelerinin, matris boyunca dağılımları, tane ve tane sınırlarına yakın bölgelerde kümelendiği tespit edilmiştir. $\mathrm{SiC}$ ve $\mathrm{B}_{4} \mathrm{C}$ seramik faz parçacık takviyelerinin artışına bağlı olarak mikro sertlik değerleri artmıştır. En yüksek sertlik değeri $\% 15 \mathrm{~B}_{4} \mathrm{C}$ seramik faz parçacık takviyesi ile $86 \mathrm{HV}$ olarak elde edilmiştir. En düşük sertlik değeri, hiçbir takviye fazı içermeyen AA 2014 alaşımında 53HV iken, hibrit kompozit malzemesinde orta seviyede bir sertlik değeri (68HV) elde edilmiştir. Bu tarzdaki hibrit kompozit yapılarının, sertlik ve süneklik kombinasyonları ile malzeme mekanik özellikleri bakımından, malzeme uygulama alanları çeşitliliği göz önünde bulundurulduğunda önemli bir katkı sağlayabileceği belirtilebilir.

\section{KAYNAKLAR (REFERENCES)}

[1] Uthayakumar, M., Aravindan, S., Rajkumar, K., "Wear performance of $\mathrm{Al}-\mathrm{SiC}-\mathrm{B}_{4} \mathrm{C}$ hybrid composites under dry sliding conditions", Materials and Design, 47: 456-464, 2013.

[2] Alizadeh, A., Taheri-Nassaj, E., "Mechanical properties and wear behavior of Al-2 wt.\% Cu alloy composites reinforced by $\mathrm{B}_{4} \mathrm{C}$ nanoparticles and fabricated by mechanical milling and hot extrusion", Materials Characterization, 67: 119-128, 2012.

[3] Abenojar, J., Velasco, F., Martinez, M. A., "Optimization of processing parameters for the $\mathrm{Al}+$ $10 \%$ B4C system obtained by mechanical alloying", Journal of Materials Processing Technology 184: 441-446, 2007.

[4] Cunzhu, N., Jiajun, G., Junliang, L., Di, Z., "Investigation on microstructures and interface character of B4C particles reinforced 2024Al matrix composites fabricated by mechanical alloying", Journal of Alloys and Compounds 454: 118-122, 2008

[5] Karagöz, Ş., Yamanoğlu, R., Atapek, Ş. H., "Solidification and Microstructural Characterization on Atomized Powders", Pamukkale University Journal of Engineering Science, 15 (3): 309-316, 2009.

[6] Gökmeşe, H., Bostan, B., "Microstructural characterization and synthesis by mechanochemical method of nanoparticle $\mathrm{Al}_{2} \mathrm{O}_{3} / \mathrm{B}_{4} \mathrm{C}$ ceramic phase", Journal of the Faculty of Engineering and Architecture of Gazi University, 29: 2, 289-297, 2014.

[7] Gökmen, U., "Fabrication and Characterization of Hot Extruded Hybrid Composites Al 2024 Matrix Reinforced with $\mathrm{B}_{4} \mathrm{C} / \mathrm{Al}_{2} \mathrm{O}_{3}$ ”, Journal of Polytechnic, 19 (4): 445-453, 2016.

[8] Bozkurt, L., "Investigation of low velocity impact behavior of hybrid stacked composite plates", Selcuk University, Graduate School of Natural and Applied Sciences Department of Mechanical Engineering, Master Thesis, 2011.

[9] Motorcu, A. R., Ekici, E., "Evaluation of drilling Al/B4C composites with carbide drills", Pamukkale University Journal of Engineering Science, 22 (4): 259-266, 2016. 
[10] Bodunrin, M.O, Alaneme, K.K., L.H., Chown "Aluminium matrix hybrid composites: a review of reinforcement philosophies; mechanical, corrosion and tribological characteristics", J Mater Res. Tech., 2015.

[11] Gökmeşe, H., Bostan, B., "Improvements of Dry Sliding Wear Behaviour and Mechanical Properties In 2014 Al Alloy By Age-Hardening", Scientific Research and Essays, 8:45, 22272234, 2013.

[12] German, Randall M., "Powder Metallurgy and Particulate Material Transactions", 05, Prof. Dr. Suleyman SARITAS, Prof. Dr. Mehmet TURKER, Doç. Dr. Nuri DURLU, Turkish Powder Metallurgy Association Publications, Ankara, 2007.

[13] Gökmeşe, H., Bostan, B., “AA 2014 Alaşımında Presleme ve Sinterlemenin Gözenek Morfolojisi ve Mikro yapısal Özelliklere Etkileri”, Gazi Üniversitesi Fen Bilimleri Dergisi Part C: Tasarım ve Teknoloji, 1(1): 1-8, 2013.

[14] Cebeci, H. A., "Mekanik alaşımlama yöntemi ile üretilen SiC takviyeli al kompozitlerin aşınma davranışlarının incelenmesi”, Yüksek Lisans Tezi, Karabük Üniversitesi Fen Bilimleri Enstitüsü, Karabük, 14-17, (2008).

[15] Dörtbölük, C., “Aluminyum matrisli kompozit malzemelerin toz metalurjisi yöntemiyle üretilmesi ve karakterizasyonu", Yüksek Lisans Tezi, Zonguldak Karaelmas Üniversitesi Fen Bilimleri Enstitüsü, Zonguldak, 4-7, (2006).

[16] Mazahery, A., Shabani., M. O., "Influence of the hard coated $\mathrm{B}_{4} \mathrm{C}$ particulates on wear resistance of Al-Cu alloys", Composites: Part B, 43: 1302-1308 (2012).

[17] Jiang, Q. C., Wang, H. Y., Ma, B. X., Wang, Y., Zhao, F., "Fabrication of $\mathrm{B}_{4} \mathrm{C}$ particulate reinforced magnesium matrix composite by powder metallurgy", Journal of Alloys and Compounds, 386: 177-181 (2005).

[18] Topçu, I., Gülsoy, H. O., Kadıglu, N., Güllüoğlu, A. N., "Processing and mechanical properties of $\mathrm{B}_{4} \mathrm{C}$ reinforced Al matrix composites", Journal of Alloys and Compounds, 482: 516-521 (2009).

[19] Baradeswaran, A., Perumal, A. E., "Study on mechanical and wear properties of Al 7075/Al2O3/graphite hybrid composites”, Composites: Part B, 56:464-471, 2014. 